\title{
ABUNDANCE AND HABITAT DIVERSITY OF SPRINGTAILS (INSECTA: COLLEMBOLA) OF RAJSHAHI CITY CORPORATION
}

\section{Mosharrof Hossain*, Mirjahan and Saiful Islam Faruki}

\author{
Department of Zoology, University of Rajshahi, Rajshahi-6205, Bangladesh \\ *Corresponding author (e-mail: mshzool@yahoo.com)
}

Keyword: Diversity, springtails, Rajshahi, collembola

Springtails are apterygote insects under the order Collembola. The common name, "springtail”, is derived from the ability of many species to leap considerable distances when disturbed. Habitat diversity refers to varieties of habitats present in a particular area. Collembola are found predominantly in the soil, and in

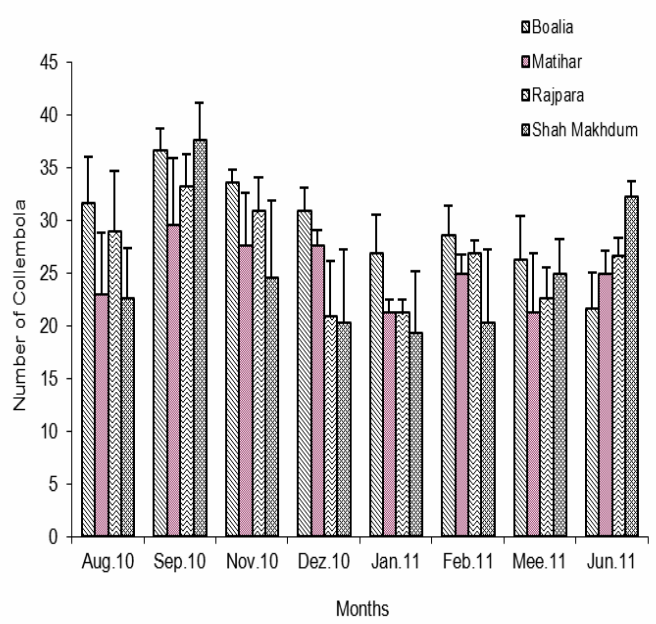

Figure 1 Population of Collembola in leaf litter during study period in four Police stations.

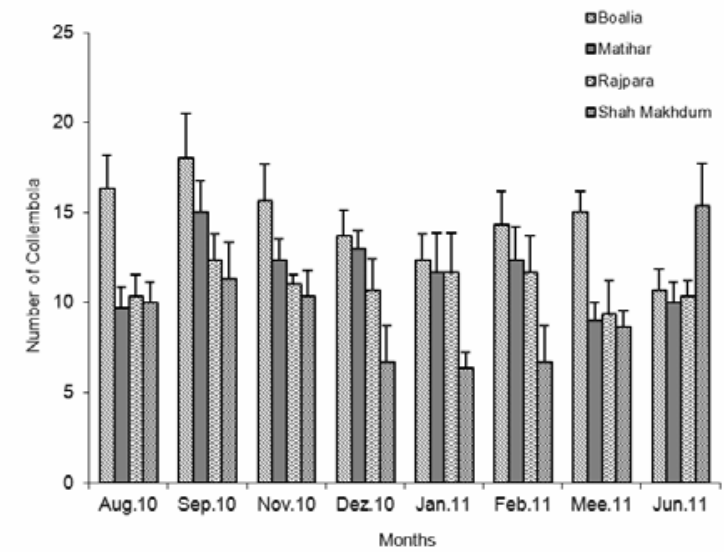

Figure 3 Population of Collembola in crop field during study period in four Police stations. leaf litter and other decomposed habitats such as logs and dung. Certain species are found on grasses, in flowers and under the bark of trees (Weis-Fogh, 1948). Collembola are virtually ubiquitous, being found in all terrestrial biomes, including mountain tops, polar

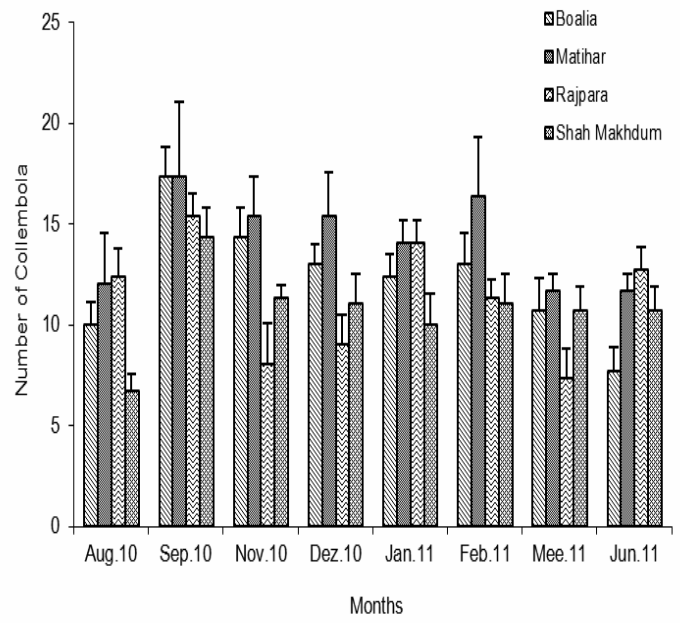

Figure 2 Population of Collembola in open grassland during study period in four Police stations.

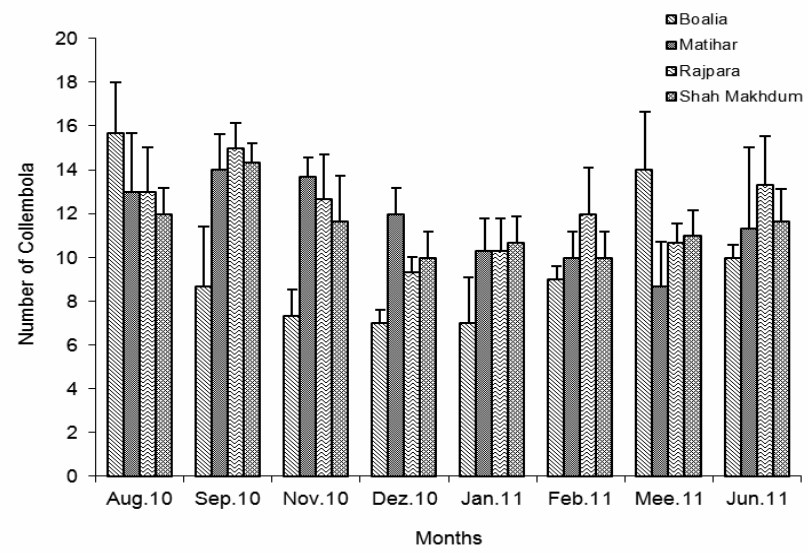

Figure 4 Population of Collembola in shady grassland during study period in four Police stations. 
regions and deserts (Butcher et al. 1971). Many species inhabit in caves. They are common also in marine and fresh water littoral habitats; occur interstitially in wet sand, on and under rocks including coral reefs, and on water surfaces (Tanaka, 1970). However, very few truley aquatic species have yet been recorded. These are minor pests in agriculture but their importance as biological agents in the soil forming process is immense (Hazra and Mandal, 2007). Many species of collembolan are now established as bio-indicators of soil pollution as well as soil fertility. Only two genera of Collembola have been recorded from Bangladesh (Hossain, 2010).

In this paper, attempts were made to study the abundance and habitat diversity of collembolan fauna in the Rajshahi City Corporation.

Collembola was collected from four Police Stations of Rajshahi City Corporation (RCC). The geographical location of Rajshahi is $24^{\circ}$ North and $89^{\circ}$ East. Eight different spots were selected for sampling in each Police Station, four spots were at the four corners and another four were selected at the middle portion of the Police Station. These eight spots were selected in such a manner that there were equal distances among these spots. Sampling was performed in four different habitats (leaf litter, open grassland, crop field and shady grassland) at each site. Collembolans at different habitats were collected by using Berlese funnel following the standard procedure.

The populations of Collembola during the study periods in different habitats are shown in Figs. 1-4. Among four types of habitats, leaf-litter contains the highest population of Collembola during the month of September 2010 in Shah Makhdum Police station (37.67 \pm 3.48$)$. In case of open grass-land the highest population of Collembola was found during the month of September 2010 in Motihar Police station (17.33 \pm 3.71$)$. Crop field habitat contained the highest population of Collembola during the month of September 2010 under Boalia Police station

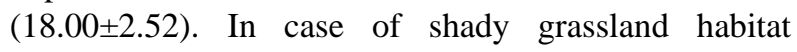
population of Collembola was found during the month of August 2010 under Boalia Police station (15.67 \pm 2.33$)$. Among the four types of habitats leaflitter contained significantly higher number of Collembola (Fig. 5). Habitat conditions related to this study determined not only the total numbers of Collembola populations but also the diversity in RCC Police stations areas. Further study is needed to assay collembolan contribution in soil ecology and taxonomy of different species.

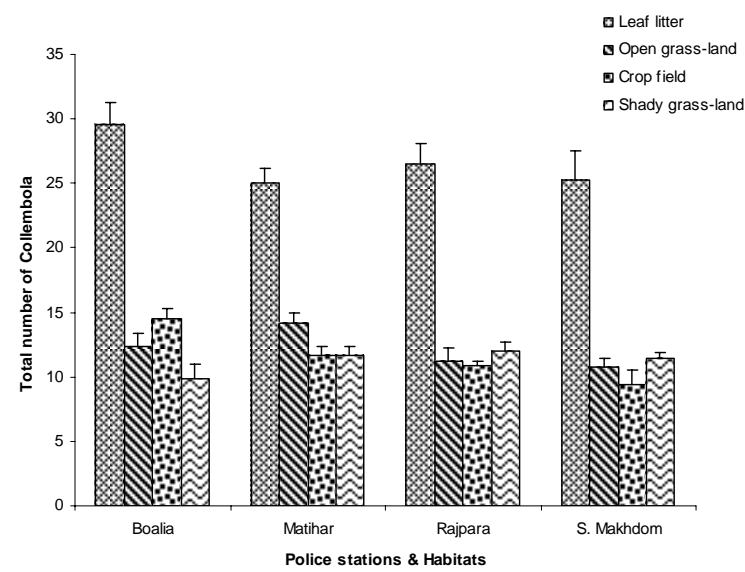

Figure 5 Total means number of Collembola found during the study period in different habitats in four Police stations.

Acknowledgement: Thanks are due to Chairman, Department of Zoology, University of Rajshahi, for providing required laboratory facilities during the progress of this work.

\section{References}

Butcher JW, Snider R and Snider RJ. 1971. Bioecology of edaphic Collembola and Acarina. A. Rev. Ent. 16: 249-288.
Hazra AK and Mandal GP. 2007. Pictorial Handbook on Indian Collembola (Par-1). Zoological Survey of India, Kolkata. 34 pp.

Hossain M. 2010. Collembolan fauna of Rajshahi University Campus. J. Life Earth Sci. 5: 33-35.

Tanaka M. 1970. Ecological studies on communities of soil Collembola in Mt. Sobo, Southwest Japan. Japanese J. Ecol. 20(3): 102-110.

Weis-Fogh T. 1948. Ecological investigations on mites and collemboles in the soil, Natura Jutlandicae 1: 135-270.

Manuscript received on 5 August 2012 and revised on 3 October 2012 